Article

\title{
$\beta$-Phenylethylamine as a Natural Food Additive Shows Antimicrobial Activity against Listeria monocytogenes on Ready-to-Eat Foods
}

\author{
Francis Muchaamba *(D), Roger Stephan ${ }^{(D)}$ and Taurai Tasara $\mathbb{D}$ \\ Institute for Food Safety and Hygiene, Vetsuisse Faculty, University of Zürich, 8057 Zürich, Switzerland; \\ stephanr@fsafety.uzh.ch (R.S.); tasarat@fsafety.uzh.ch (T.T.) \\ * Correspondence: francis.muchaamba@uzh.ch
}

Received: 20 August 2020; Accepted: 23 September 2020; Published: 25 September 2020

\begin{abstract}
Listeria monocytogenes is an important foodborne pathogen and a major cause of death associated with bacterial foodborne infections. Control of L. monocytogenes on most ready-to-eat (RTE) foods remains a challenge. The potential use of $\beta$-phenylethylamine (PEA) as an organic antimicrobial against $L$. monocytogenes was evaluated in an effort to develop a new intervention for its control. Using a collection of 62 clinical and food-related isolates we determined the minimum inhibitory concentration (MIC) of PEA against L. monocytogenes in different broth and agar media. Bologna type sausage (lyoner) and smoked salmon were used as food model systems to validate the in vitro findings. PEA had a growth inhibitory and bactericidal effect against $L$. monocytogenes both in in vitro experiments as well as on lyoner and smoked salmon. The MIC's ranged from 8 to $12.5 \mathrm{mg} / \mathrm{mL}$. Furthermore, PEA also inhibited L. monocytogenes biofilm formation. Based on good manufacturing practices as a prerequisite, the application of PEA to RTE products might be an additional hurdle to limit L. monocytogenes growth thereby increasing food safety.
\end{abstract}

Keywords: $\beta$-phenylethylamine; antimicrobial; Listeria monocytogenes; bologna type sausage; cold smoked salmon

\section{Introduction}

Listeria monocytogenes is an important foodborne pathogen and a major cause of death associated with bacterial foodborne infection [1,2]. An association between contaminated ready-to-eat (RTE) food in outbreaks and sporadic listeriosis infections is well documented [1-9]. Deli meats are amongst the most common foods linked to such outbreaks, an example being the recent and largest listeriosis outbreak in history recorded in South Africa, where polony, a commonly consumed bologna type sausage deli meat product, was implicated as the source of the outbreak [3,8,10-14]. Recent data from the European Union (EU) member states show that L. monocytogenes is isolated at different frequencies from RTE products $[2,15]$. The occurrence of $L$. monocytogenes in RTE foods coupled with the increase of susceptible populations and changing eating patterns that favor high risk foods such as RTE foods like salads and deli meats raises concerns [16-19]. As a result, a zero-tolerance policy for L. monocytogenes on RTE foods has been adopted by countries such as the USA [20,21]. Meanwhile, the EU has adopted a stern policy concerning L. monocytogenes in foodstuffs which can support the growth of this bacterium or are intended for the high-risk populations [22]. This has forced food processing companies to employ a variety of hurdle procedures in an effort to ensure that their food products are L. monocytogenes-free [23-25]. Several technologies and intervention strategies aimed at inhibiting or killing these pathogens thereby improving the microbiological quality have been employed albeit with varying levels of success [26-36]. 
High hydrostatic pressure (HHP), phage biocontrol, bacteriocin-producers, or bioprotective cultures, nisin, sodium chloride, sodium lactate, and other food-grade antimicrobials are some of the treatments and techniques used to increase the safety of RTE food products [28-33,37-40]. These measures can prolong product shelf life, which is critical due to the globalization of the food industry, as food is often transported over long distances before consumption [41]. However, with prolonged use, bacteria tend to become resistant to most such interventions or antimicrobial treatments. This is well documented for interventions such as salt and nisin to mention a few [42-48]. In the case of acid, cold and salt resistance, bacteria pre-exposed to these stresses can be inadvertently primed for gastric stress and intracellular life increasing their virulence e.g., they survive the acid barrier of the stomach much better [49-52]. Moreover, most of these treatments have the limitation that many consumers are favoring products with less of these treatments, while producers are aspiring to limit the use of additives, especially nonorganic ones [29].

L. monocytogenes control is further compounded by the bacterium's ability to survive harsh conditions commonly encountered in foods which include low temperature, low water activity, oxidative and osmotic stress, low $\mathrm{pH}$, or desiccation [37,53-56]. In addition, this bacterium can grow at refrigeration temperature, which is particularly significant in cases of temperature abuse $[7,24,25,42,48,57,58]$. To achieve this L. monocytogenes deploys various regulatory protein systems that control the implementation of the necessary stress adaption and virulence responses, which allow stress survival and transmission along the food chain as well as subsequently target host infection and pathogenicity [46,54-56]. Moreover, the common occurrence of L. monocytogenes in the environment makes its introduction into processing plants highly likely. Once introduced, several factors including biofilm production and tolerance of disinfectants increase the probability of L. monocytogenes to establish and persist in a facility $[3,14,54,59-62]$. As such, L. monocytogenes continues to be a costly control challenge for the food industry especially given its ability to persist in food producing facilities for long periods, in some cases, eventually causing outbreaks [14,35,60-64].

In an aim to mitigate the impacts of food contamination, manufacturers and researchers are therefore exploring new avenues to improve food safety and eliminate L. monocytogenes from their facilities. Current research on the development of novel techniques to reduce bacterial contamination of food is aimed at substances or interventions that can alter growth phenotypes of bacteria increasing shelf life and safety of foods [29,65]. Moreover, the search is being directed towards natural substances as consumers are becoming more particular of what their food contains with an increased demand for more organic natural food on the rise in the market $[33,38,66,67]$. One such substance that fits in this natural additive category is $\beta$-phenylethylamine (PEA) that has been shown to have antimicrobial activity against bacteria such as Escherichia coli, Pseudomonas aeruginosa, and Staphylococcus aureus in settings such as beef, biofilms, and clinical environments (as a liquid catheter flush) $[65,68,69]$. Though PEA is at present not accepted as a food preservative in the EU, it would be ideal for food applications due to its GRAS status (Generally Regarded As Safe) and does not constitute a known health hazard to humans $[65,68,69]$. PEA is, however, currently approved for use as a flavoring agent in several countries including those of the EU [70,71]. Moreover, PEA is a relatively inexpensive naturally occurring trace substance found in chocolate [65,69], where its concentration increases during cocoa fermentation $[65,72]$. PEA is currently sold by many health companies for various reasons including mood enhancement and to aid weight loss, with its intake as a nutritional supplement currently recommended at $500 \mathrm{mg}$ per day or more in some cases $[68,69]$.

We recently observed inhibition patterns of L. monocytogenes upon PEA inclusion to growth media under alkaline stress conditions [73,74]. This suggested that PEA could also be potentially exploited in developing novel ways to control L. monocytogenes in foods. In this study, we took advantage of this observation and used it to establish the minimum inhibitory and bactericidal concentration of PEA against L. monocytogenes. Furthermore, the practical applicability of this concept was further tested on cold smoked salmon and a bologna type sausage product (lyoner), for the development of a novel control strategy against L. monocytogenes on such RTE products. This was motivated 
by the fact that a type of bologna sausage called polony and other processed meats were recently associated with the biggest listeriosis outbreak in history, with more than 1000 confirmed cases, and at least 216 deaths [10]. Furthermore, seafood makes up a significant portion of food recalled due to L. monocytogenes contamination [2,15]. Control and prevention of L. monocytogenes contamination of cold-smoked fish products such as cold-smoked salmon continues to be a challenge mainly due to the intrinsic characteristics of these products that support the growth of L. monocytogenes [39,75-78]. Therefore, the development of novel control strategies for L. monocytogenes in bologna type sausages and cold-smoked salmon is of crucial importance for these industries.

\section{Materials and Methods}

\subsection{Bacterial Strains and Culture Conditions}

Sixty-two strains covering the biodiversity of L. monocytogenes including food-derived isolates, outbreak and sporadic listeriosis isolates as well as EGDe the L. monocytogenes reference strain were analyzed (Table 1). The study strains used covered clinical and food relevant genetic backgrounds of L. monocytogenes (Supplementary Figure S1). Frozen stocks of the strains were kept in a cryo-preservative mixture of brain heart infusion medium (BHI, Oxoid, UK) and glycerol $(20 \%)$ at $-80^{\circ} \mathrm{C}$. Aliquots from the frozen stock were streaked out on BHI or blood agar plates and incubated overnight at $37^{\circ} \mathrm{C}$ to get single colonies. To prepare working inoculum, single colonies of each strain were picked and pre-cultured twice $\left(16 \mathrm{~h}, 37^{\circ} \mathrm{C}\right.$ and $\left.150 \mathrm{rpm}\right)$ in $\mathrm{BHI}$ broth, generating secondary stationary phase cultures that were subsequently used in our experiments.

Table 1. Study strains and their PEA MIC in different media.

\begin{tabular}{|c|c|c|c|c|c|c|c|}
\hline Strain ID & Source & $S_{T}^{d}$ & $C^{d}$ & Serotypes & Lineage & Reference & $\begin{array}{l}\text { PEA MIC } \\
(\mathrm{mg} / \mathrm{mL})^{c}\end{array}$ \\
\hline $\mathrm{N} 2306^{\mathrm{a}, \mathrm{b}}$ & Ready-to-eat salads & ST4 & CC4 & $4 b$ & I & [9] & 10 \\
\hline N14-195 & Meat/Meat product & ST31 & CC31 & $4 b$ & I & [80] & 10 \\
\hline N16-0044 a,b & Meat pâté & ST6 & CC6 & $4 b$ & I & [11] & 10 \\
\hline H34 & Human listeriosis & ST489 & CC489 & $1 / 2 b$ & I & [81] & 10 \\
\hline N11-2675 & human listeriosis & ST1063 & CC5 & $1 / 2 b$ & I & [82] & 10 \\
\hline N14-0435 & Milk product & ST3 & CC3 & $1 / 2 b$ & I & [80] & 10 \\
\hline N14-0487 & Plant associated & ST4 & CC4 & $4 b$ & I & [80] & 10 \\
\hline N12-0605 & Meat/Meat product & ST727 & CC1 & $4 b$ & I & [80] & 10 \\
\hline N12-1339 & Meat/Meat product & ST746 & CC1 & $4 b$ & I & [80] & 10 \\
\hline N12-0341 & human listeriosis & ST1 & CC1 & $4 b$ & I & [82] & 10 \\
\hline N12-0551 & human listeriosis & ST1 & CC1 & $4 b$ & I & [82] & 10 \\
\hline N12-0320 & human listeriosis & ST4 & CC4 & $4 b$ & I & [82] & 10 \\
\hline N12-0794 & human listeriosis & ST4 & $\mathrm{CC} 4$ & $4 b$ & I & [82] & 10 \\
\hline N13-2107 & Meat/Meat product & ST4 & CC4 & $4 b$ & I & [80] & 10 \\
\hline N13-1054 & human listeriosis & ST1285 & $\mathrm{CC} 2$ & $4 b$ & I & [82] & 10 \\
\hline N12-1387 & human listeriosis & ST6 & CC6 & $4 b$ & I & [82] & 10 \\
\hline N11-2801 & human listeriosis & ST6 & CC6 & $4 b$ & I & [82] & 10 \\
\hline $\mathrm{N} 12-1772 \mathrm{a}^{\mathrm{a}}$ & Milk/Milk product & ST682 & $\mathrm{CC} 4$ & $4 b$ & I & [80] & 10 \\
\hline N13-1184 & Meat/Meat product & ST6 & CC6 & $4 b$ & I & [80] & 10 \\
\hline $\mathrm{N} 1546^{\mathrm{a}}$ & Imported cooked ham & ST8 & $\mathrm{CC} 8$ & $1 / 2 \mathrm{a}$ & II & [8] & 10 \\
\hline
\end{tabular}


Table 1. Cont.

\begin{tabular}{|c|c|c|c|c|c|c|c|}
\hline Strain ID & Source & $S T^{d}$ & $\mathrm{CC}^{\mathrm{d}}$ & Serotypes & Lineage & Reference & $\begin{array}{l}\text { PEA MIC } \\
\left(^{(m g / m L}\right)^{c}\end{array}$ \\
\hline $\operatorname{Lm} 3136^{a}$ & Tomme cheese & ST18 & CC18 & $1 / 2 \mathrm{a}$ & II & [85] & 10 \\
\hline Lm3163a & Tomme cheese & ST26 & CC26 & $1 / 2 \mathrm{a}$ & II & [85] & 10 \\
\hline N586 & Human prosthetic joint & ST412 & CC412 & $1 / 2 \mathrm{a}$ & II & [74] & 10 \\
\hline N843 & Human prosthetic joint & ST412 & CC412 & $1 / 2 \mathrm{a}$ & II & [74] & 10 \\
\hline $\mathrm{EGDe}^{\mathbf{a}, \mathbf{b}}$ & Rabbits & ST35 & CC9 & $1 / 2 \mathrm{a}$ & II & [86] & 8 \\
\hline N11-1515 & Milk product & ST29 & CC29 & $1 / 2 \mathrm{a}$ & II & [80] & 10 \\
\hline N11-1617 & Meat/Meat product & ST8 & CC 8 & $1 / 2 \mathrm{a}$ & II & [80] & 10 \\
\hline N11-2183 & Plant associated & ST20 & CC20 & $1 / 2 \mathrm{a}$ & II & [80] & 10 \\
\hline $\mathrm{D}: 824 / 5$ & Meat product & ST9 & CC9 & $3 c$ & II & [80] & 10 \\
\hline N11-1514 & Meat/Meat product & ST9 & CC9 & $1 / 2 c$ & II & [80] & 10 \\
\hline N12-1921 & Plant associated & ST9 & CC9 & $1 / 2 c$ & II & [80] & 10 \\
\hline D: $650 / 8$ & Meat/Meat product & ST9 & CC9 & $3 c$ & II & [80] & 10 \\
\hline N12-0152 & Milk/Milk product & ST9 & CC9 & $1 / 2 a$ & II & [80] & 10 \\
\hline N11-1837 & human listeriosis & ST9 & CC9 & $1 / 2 \mathrm{a}$ & II & [82] & 10 \\
\hline N12-0486 & human listeriosis & ST9 & CC9 & $1 / 2 c$ & II & [82] & 10 \\
\hline N13-0001 & human listeriosis & ST9 & CC9 & $1 / 2 c$ & II & [82] & 10 \\
\hline N12-1864 & Milk/Milk product & ST9 & CC9 & $1 / 2 \mathrm{a}$ & II & [80] & 10 \\
\hline N11-1649 & Meat/Meat product & ST743 & $\mathrm{CC} 8$ & $1 / 2 \mathrm{a}$ & II & [80] & 10 \\
\hline N11-1584 & human listeriosis & ST1295 & $\mathrm{CC} 8$ & $1 / 2 a$ & II & [82] & 10 \\
\hline N12-1273 & Human listeriosis & ST412 & CC412 & $1 / 2 a$ & II & [82] & 10 \\
\hline N11-1346 & Human listeriosis & ST673 & CC8 & $1 / 2 a$ & II & [82] & 12.5 \\
\hline N11-1905 & Meat/Meat product & ST121 & CC121 & $1 / 2 a$ & II & [80] & 10 \\
\hline N12-1024 & Meat/Meat product & ST121 & CC121 & $1 / 2 a$ & II & [80] & 10 \\
\hline N13-0119a & human listeriosis & ST121 & CC121 & $1 / 2 \mathrm{a}$ & II & [82] & 10 \\
\hline N12-0367 & human listeriosis & ST121 & CC121 & $1 / 2 a$ & II & [82] & 10 \\
\hline WSLC1019 & Animal isolate & ST130 & CC69 & $4 \mathrm{c}$ & III & $\begin{array}{l}\text { ATCC } \\
19116\end{array}$ & 10 \\
\hline LMNC318 a & Ruminant listeriosis & ST70 & CC70 & $4 a / 4 c$ & III & [87] & 12.5 \\
\hline $\mathrm{LMNC} 326^{\mathrm{a}}$ & Ruminant listeriosis & ST70 & CC70 & $4 \mathrm{a} / 4 \mathrm{c}$ & III & [87] & 12.5 \\
\hline WLSC1020 & Animal isolate & ST71 & CC131 & $4 a$ & III & $\begin{array}{l}\text { ATCC } \\
19114\end{array}$ & 10 \\
\hline
\end{tabular}

a Strains used in the biofilm assays as well as assays to evaluate heat stability of PEA activity against L. monocytogenes.

${ }^{\mathbf{b}}$ Strains used in assays to evaluate the effect of PEA on L. monocytogenes using food models. ${ }^{\mathbf{c}}$ PEA MIC for each strain in BHI broth, BHI agar, meat simulation media (MSM), heat treated BHI (HT BHI) and heat treated MSM (HT MSM). ${ }^{\mathrm{d}}$ ST: sequence type, CC: clonal complex.

\subsection{Growth Evaluation and MIC Determination}

Secondary cultures prepared from each strain were diluted in BHI to $10^{7}$ colony forming units $(\mathrm{CFU}) / \mathrm{mL}$. To evaluate growth under $\beta$-Phenylethylamine hydrochloride (PEA), (Sigma-Aldrich Chemie $\mathrm{GmbH}$, Steinheim, Germany) and determine the minimum inhibitory concentration (MIC), $100 \mu \mathrm{L}$ of BHI containing $0,3.13,6.25,12.5,16,20,25,50,100$, and $150 \mathrm{mg} / \mathrm{mL}$ PEA were pipetted in triplicate to a 96-well microplate that had been pre-filled with $100 \mu \mathrm{L}$ of the diluted $\left(10^{7} \mathrm{CFU} / \mathrm{mL}\right)$ secondary cultures of the different strains. The cultures were incubated continuously shaking for $24 \mathrm{~h}$ at $37^{\circ} \mathrm{C}$, with optical density (OD) being measured at $600 \mathrm{~nm}$ every $30 \mathrm{~min}$ in an OD reader (Synergy $\mathrm{HT}$, BioTek Instruments, $\mathrm{GmbH}$, Switzerland). Similar growth experiments were repeated using meat simulation media (MSM) instead of $\mathrm{BHI}$. From the $\mathrm{OD}_{600}$ growth data, growth kinetics such as lag phase duration, maximal growth rate, and area under the curve (AUC) were determined using the program DMFit [88] and Graphad Prism, respectively. To assess for respiration as an indicator of growth or nutrient utilization the same experimental setup was also repeated but using BHI media supplement with $0.05 \%$ of the respiration indicator dye 2,3,5-triphenyltetrazolium chloride (TTC) (Sigma-Aldrich Chemie GmbH, Steinheim, Germany). To determine viable bacterial cell counts, cultures from each 96 well plate (from plates without TTC dye) were serially diluted in phosphate buffered saline (PBS), plated onto BHI plates, and incubated overnight at $37^{\circ} \mathrm{C}$. Viable cell counting was similarly performed on selected strains (covering the three genetic lineages and distributed over the entire observed PEA MIC range) that had been incubated in BHI at their respective PEA minimum inhibitory concentrations 
for 24 and $48 \mathrm{~h}$. Viable bacterial cell counts were expressed in colony forming units (CFU) per $\mathrm{ml}$ of original broth (limit of detection: $1 \mathrm{CFU} / \mathrm{mL}$; limit of quantitation: 25-250 CFU/plate). Normalized relative inhibition factors for each PEA concentration were calculated by dividing the viable bacterial cell counts $(\mathrm{CFU} / \mathrm{mL})$ of each strain by the counts of the un-supplemented $(0 \mathrm{mg} / \mathrm{mL} \mathrm{PEA})$ positive controls. The mean and standard deviations across the biological replicates were calculated and plotted against the respective concentration. The above-mentioned PEA concentrations were also further accessed for their inhibitory power on solid media when formulated in BHI agar, this criterion yielded concentrations which were then used for the food matrix (lyoner and smoked salmon) assays. The water activity and $\mathrm{pH}$ of all working solutions containing PEA as well as the solvent were measured using an AQUALAB water activity meter (Decagon Devices Inc, Pullman, WA, USA) and pH-Indicator paper and $\mathrm{pH}$-indicator strips (non-bleeding) ( $\mathrm{pH}$ range 1 to 10) (Merck KGaA, Darmstadt, Germany). The $\mathrm{pH}$ values were also validated by measurement with a Thermo Scientific ${ }^{\mathrm{TM}}$ Orion $^{\mathrm{TM}}$ Star A111 $\mathrm{pH}$ meter (Loughborough, UK).

\section{Microscopy}

The $100 \mu \mathrm{L}$ aliquots of the cultures were spread onto microscopic slides, fixed and Gram-stained. Slides were microscopically examined for bacterial chaining levels with an Olympus BX40 microscope through a 100x/1.3 oil-immersion objective.

\subsection{Effect of PEA on L. monocytogenes on RTE Food Models}

Sliced lyoner sausage and Norwegian smoked salmon packages purchased from a local Swiss retailer were surface decontaminated using 70\% ethanol. The packages were aseptically opened and the individual slices weighing $11 \mathrm{~g}$ each (lyoner slice diameter $10 \mathrm{~cm}$ ) were placed on separate clean $145 \times 20 \mathrm{~mm}$ petri dishes. A four-strain bacterial inoculum mixture $\left(10^{8} \mathrm{CFU} / \mathrm{mL}\right)$ prepared in PBS was centrifuged (10 $\mathrm{min}$ at $6000 \times g$ and room temperature) and washed once in PBS. The inoculum strain selection included the L. monocytogenes EGDe reference strain, two isolates (N1546, N16-0044) from meat associated listeriosis outbreaks and strain LL195 from the 1983-1987 Swiss listeriosis outbreak. The concentration of the bacterial inoculum was confirmed by plating out serial dilutions onto BHI plates and determining the $\mathrm{CFU} / \mathrm{mL}$ counts. To rule out possible pre-existing natural L. monocytogenes contamination in the lyoner and smoked salmon preparations controls of un-inoculated slices (one per experiment) were included within each experimental run. PEA weighing 82.5, 110, 165, and $220 \mathrm{mg}$ were each dissolved in $250 \mu \mathrm{L}$ sterile deionized water. Two hundred and fifty microliters of each PEA solution were applied in a dropwise manner over one side of the respective meat or salmon slices and evenly distributed using a sterile L-shaped spreader giving final PEA concentrations of 7.5, 10, 15 , and $20 \mathrm{mg} / \mathrm{g}$. As a positive control, one slice was similarly treated using sterile deionized water without PEA. The meat slices were dried at $4{ }^{\circ} \mathrm{C}$. Then $11 \mu \mathrm{L}$ of bacterial inoculum $\left(10^{8} \mathrm{CFU} / \mathrm{mL}\right)$ was applied over the treated side of the meat slices and similarly spread. One uninoculated negative control, one deionized water treated inoculated positive control and PEA treated inoculated meat slices from each RTE meat type per experiment were stored for 7 and 11 days at $10{ }^{\circ} \mathrm{C}$ and $4{ }^{\circ} \mathrm{C}$, respectively. Then the meat slices were separately placed in a sterile stomacher bag with $99 \mathrm{~mL}$ PBS and homogenized at normal grade for $2 \mathrm{~min}$ in a Laboratory Blender Stomacher 400 (Seward, Worthing, UK). Resulting homogenates were serially diluted and plated onto Oxoid chromogenic Listeria agar (OCLA) for L. monocytogenes enumeration. Plates were incubated at $37^{\circ} \mathrm{C}$ and viable bacterial counts were determined after $24 \mathrm{~h}$. To assess bacterial chaining under PEA stress $100 \mu \mathrm{L}$ aliquots derived from the diluted homogenates were also microscopically examined. Viable bacteria cell counts determined from the PEA treated samples were divided by those determined for the non-PEA treated positive control to determine the relative inhibition factor. All experiments were repeated independently on three separate occasions. Results showing the mean and standard deviation from three biological replicates are presented. 


\subsection{Evaluation of Heat Stability of PEA Activity against L. monocytogenes}

To assess the heat stability of PEA, lyoner production temperature conditions were simulated. MSM and BHI broth solutions containing 0 and $150 \mathrm{mg} / \mathrm{mL}$ PEA were heated to $80^{\circ} \mathrm{C}$ in a water bath and held for $10 \mathrm{~min}$ at $80^{\circ} \mathrm{C}$. Thereafter, the broths were cooled and diluted to prepare working solutions supplemented with $0,3.125,6.25,12.5,16,20$, and $25 \mathrm{mg} / \mathrm{mL}$ PEA. These solutions were subsequently used in growth evaluation and MIC determination on a subset of 12 strains (Table 1) to determine PEA heat stability.

\subsection{Biofilm Assay}

The effect of PEA on biofilm formation was assessed at $25^{\circ} \mathrm{C}$ in Tryptone soy broth (TSB) medium for a selection of $12 \mathrm{~L}$. monocytogenes strains (Table 1). This strain selection represented all three L. monocytogenes lineages and covered the entire PEA MIC diversity of our strain collection and included the high biofilm producing L. monocytogenes strain N11-1850. Secondary TSB cultures were prepared from these strains as described above and diluted (1:40) in fresh TSB medium. A hundred microliters $\left(10^{7} \mathrm{CFU} / \mathrm{mL}\right)$ of each of the diluted culture was added to respective wells of a flat bottomed 96-well polystyrene microtiter plate prefilled with an equal volume of TSB containing 0, 6.25 and $12.5 \mathrm{mg} / \mathrm{mL}$ PEA. Appropriate lids were placed on the plates and sealed with parafilm, and then biofilms were grown for $96 \mathrm{~h}$ at $25^{\circ} \mathrm{C}$, after which $100 \mu \mathrm{L}$ from each well was transferred to a corresponding well of a new 96 well plate. The growth in each well was measured at $600 \mathrm{~nm}$ (using a Synergy HT OD reader) to allow for calculation of biofilm formation relative to growth. To remove unbound cells each well was rinsed 3 times with $200 \mu \mathrm{L}$ sterile deionized water. At each rinse step, remnant wash solution was removed by inversion and gentle tapping of the 96 well plate on absorbent paper. The 96-well plates were dried for $30 \mathrm{~min}$ at $37^{\circ} \mathrm{C}$, after which cells bound in the biofilms were stained with $150 \mu \mathrm{L}$ $1 \%$ aqueous crystal violet for $20 \mathrm{~min}$. Excess stain was removed, and then the wells were rinsed 5 times with deionized water. After drying for $30 \mathrm{~min}$ at $37^{\circ} \mathrm{C}, 100 \mu \mathrm{L}$ of $96 \%$ ethanol was added to each well to dissolve the crystal violet within the bound stained cells. The dissolved stain was then quantified by measuring at $595 \mathrm{~nm}$ using an OD reader (Synergy HT, Biotek Instruments, GmbH, Switzerland).

\subsection{Statistics}

For all experiments done in this study, at least three independent biological replicates were performed unless stated otherwise. Statistical analysis of data was carried out using GraphPad Prism (Version 8.3.0 (328), GraphPad Software, San Diego, CA, USA). Significance of differences between the treatments or strains were identified through one-way ANOVA with post-hoc Tukey HSD tests, considering $p$ values $<0.05$ to be statistically significant.

\section{Results}

\subsection{Evaluation of PEA Antimicrobial Effects against L. monocytogenes in BHI and MSM Broth Media}

The antimicrobial effect of PEA was assessed in BHI broth revealing that it inhibited the growth of $L$. monocytogenes in a concentration and strain dependent manner. Significant growth inhibition was observed starting as low as $1.56 \mathrm{mg} / \mathrm{mL}$ PEA (Figure 1A). PEA prolonged lag phase and reduced growth rate and overall AUC (Supplementary Table S1). The MICs determined across the $62 \mathrm{~L}$. monocytogenes strains examined ranged from 8 to $12.5 \mathrm{mg} / \mathrm{mL}$ (Figure 1B, Tables 1 and 2; Supplementary Tables S2 and S3). Examining PEA inhibition on BHI agar also showed similar MICs and trends for the strains as observed in BHI broth (Table 1; Supplementary Table S2). PEA supplementation of the $\mathrm{BHI}$ and MSM working solutions did not alter their overall $\mathrm{pH}$ and water activity (Supplementary Table S4). PEA inhibition was also evaluated in MSM broth showing that although maximum cell densities achieved by the L. monocytogenes strains were lower in this media than in BHI the PEA MICs observed for the strains were similar (Table 1). While assessing growth in TTC supplemented BHI broth there was no respiratory activity detected in L. monocytogenes cultures that were cultivated at 
PEA concentrations that were equivalent or above the strain specific MIC, indicating that the PEA applied at such concentrations did not only inhibit growth but also bacterial respiration or metabolic activity (data not shown). Determination and comparison of viable bacterial cell counts before and after exposure to PEA at MIC showed that in addition to growth inhibition PEA also had a bactericidal effect on L. monocytogenes (Figure 2; Supplementary Figure S2). The observed bactericidal effects varied between the strains ranging from 1 to $8 \log \mathrm{CFU} / \mathrm{mL}$ for a tested selection of 11 strains observed at 24 and $48 \mathrm{~h}$ of incubation at strain specific PEA MICs in BHI broth (Figure 2). Notably, the strain L. monocytogenes EGDe used as a reference strain turned out to be the most sensitive exhibiting the highest sensitivity to PEA bactericidal effects and having the lowest PEA MIC amongst the tested strains (Table 1; Figure 2). When assessing the stability of PEA inhibitory effects under simulated lyoner heat treatment conditions in both MSM and BHI broths we observed that these heat treatment conditions (10 min at $80^{\circ} \mathrm{C}$ ) had no negative impact on the PEA inhibitory capacity as similar MICs were determined for selected strains before and after the heat treatment (Table 1; Supplementary Table S2). Overall there were no observable differences in bacterial chaining observed among the strains for all the different experimental setups (data not shown), ruling out the possibility that differences observed in the viable bacterial cell (CFU) counts in our study could have been distorted due to differences in bacterial chaining under the different PEA treatment conditions.
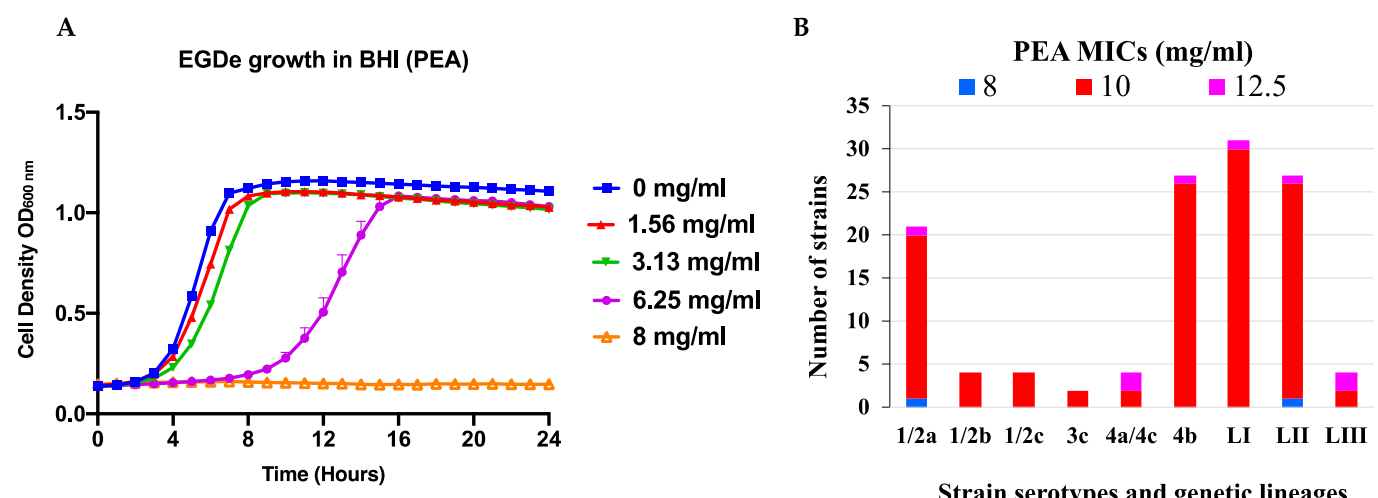

Strain serotypes and genetic lineages

Figure 1. Evaluation of $\beta$-phenylethylamine (PEA) inhibitory effect against L. monocytogenes. (A) Growth curves of L. monocytogenes EGDe in brain heart infusion (BHI) broth supplemented with increasing PEA concentrations at $37^{\circ} \mathrm{C}$. Presented are growth curves from a representative reference strain EGDe plotted from mean $\mathrm{OD}_{600}$ measurement from three replicate experiments observed from kinetic growth assays in BHI supplemented with PEA. (B) Distribution of PEA minimum inhibitory concentrations with respect to serotypes and genetic lineages (L) of the 62 L. monocytogenes strains examined.

Table 2. Serotype, lineage, and PEA MICs.

\begin{tabular}{|c|c|c|c|c|}
\hline & \multicolumn{3}{|c|}{ PEA MIC $^{a}$} & \multirow{2}{*}{ Total } \\
\hline & $8 \mathrm{mg} / \mathrm{mL}$ & $10 \mathrm{mg} / \mathrm{mL}$ & $12.5 \mathrm{mg} / \mathrm{mL}$ & \\
\hline \multicolumn{5}{|c|}{ Serotype } \\
\hline $1 / 2 a$ & 1 & 19 & 1 & 21 \\
\hline $1 / 2 b$ & - & 4 & - & 4 \\
\hline $1 / 2 \mathrm{c}$ & - & 4 & - & 4 \\
\hline $3 c$ & - & 2 & - & 2 \\
\hline $4 a / 4 c$ & - & 2 & 2 & 4 \\
\hline $4 b$ & - & 26 & 1 & 27 \\
\hline \multicolumn{5}{|c|}{ Lineage } \\
\hline LI & - & 30 & 1 & 31 \\
\hline LII & 1 & 25 & 1 & 27 \\
\hline LII & - & 2 & 2 & 4 \\
\hline
\end{tabular}

a PEA MIC reported were determined in BHI broth, BHI agar, and MSM. 
Survival in BHI (PEA)

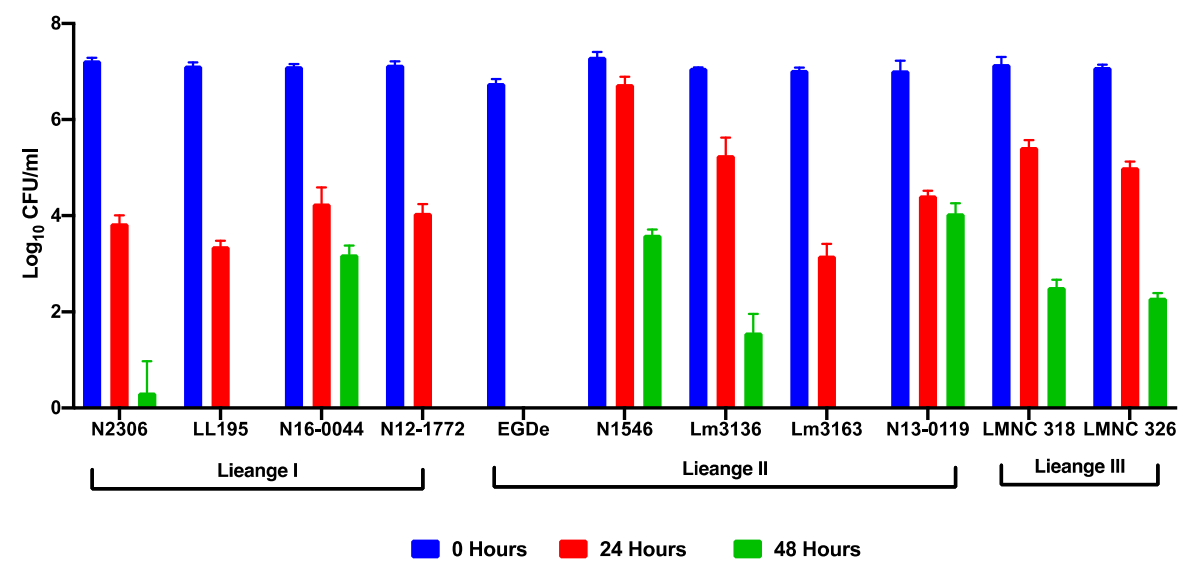

Figure 2. PEA has bactericidal activity against L. monocytogenes. Survival rates of a representative selection of 11 L. monocytogenes strains determined after 24 and $48 \mathrm{~h}$ of exposure to PEA MIC in BHI at $37^{\circ} \mathrm{C}$. Presented data show mean $\log _{10}$ colony forming units (CFU) counts (bars) and standard deviation of three biological replicates at 0 (start of incubation), 24 and $48 \mathrm{~h}$ of incubation at PEA MIC. For all strains, there was a significant difference between cell counts at each of their respective sampling time points at $p<0.05$ according to one-way ANOVA and Tukey post-hoc test pairwise comparison of all the treatment conditions.

\subsection{PEA Is an Effective Inhibitor of L. monocytogenes on Meat and Salmon}

The antimicrobial activity of PEA against L. monocytogenes on RTE foods was assessed using lyoner and cold smoked salmon products as models. Lyoner sausage and smoked salmon slices surfaced coated with varying PEA concentrations were inoculated with $L$. monocytogenes $\left(1.56 \times 10^{5} \mathrm{CFU} /\right.$ slice giving approximately $1.36 \times 10^{4} \mathrm{CFU} / \mathrm{g}$ ) and stored at $4{ }^{\circ} \mathrm{C}$ and $10^{\circ} \mathrm{C}$ for 11 and 7 days, respectively. No L. monocytogenes was detected on all the negative control slices of the lyoner sausage and salmon that had not been PEA treated and not inoculated, indicating that all meat batches used in our experiments, if any, had levels of natural Listeria contamination that were below the detection limit of the assay used. On positive control meat samples inoculated with Listeria but not PEA treated the L. monocytogenes inoculum had grown by an average of $2.58 \log$ CFU on lyoner slices, but no growth was observed on the smoked salmon slices after 11 days of storage at $4{ }^{\circ} \mathrm{C}$ (Figure $3 \mathrm{~A}, \mathrm{~B}$ and Figure 4A,B; Supplementary Figures S3A and S4A). Whereas, in those samples incubated 7 days at $10^{\circ} \mathrm{C}$ the positive control samples had average growths of 3.55 and $0.21 \log$ per slice on the lyoner and smoked salmon samples, respectively (Figure 3C,D and Figure 4C,D; Supplementary Figures S3B and S4B). As such, L. monocytogenes grew better on lyoner than on salmon and growth observed at $10^{\circ} \mathrm{C}$ was greater than that at $4{ }^{\circ} \mathrm{C}$ in the absence of PEA treatment (Figures 3 and 4). PEA application caused L. monocytogenes growth inhibition on both lyoner and salmon slices (Figures 3 and 4; Supplementary Figures S3 and S4). Compared to the positive control samples there was significant L. monocytogenes growth inhibition observed on the lyoner slices incubated at both $4{ }^{\circ} \mathrm{C}$ and $10^{\circ} \mathrm{C}$ (Figure 3). Meanwhile in the case of PEA treated salmon slices statistically significant inhibition of L. monocytogenes growth was observed in samples incubated at $10{ }^{\circ} \mathrm{C}$ whilst at $4{ }^{\circ} \mathrm{C}$ significant difference was only noted on the highest tested PEA concentration $(20 \mathrm{mg} / \mathrm{g})$ in comparison to the positive control (Figure 4).

The PEA treatment caused a 0 to $2.12 \log _{10} \mathrm{CFU}$ and 0 to $2.1 \log _{10} \mathrm{CFU}$ reduction in final bacterial cell counts at concentrations between $7.5 \mathrm{mg} / \mathrm{g}$ to $20 \mathrm{mg} / \mathrm{g}$ on lyoner at $4{ }^{\circ} \mathrm{C}$ and $10{ }^{\circ} \mathrm{C}$, respectively, in comparison to the cell counts from the positive control (Figure 3). Meanwhile, on smoked salmon PEA treatment caused a 0 to $0.17 \log _{10}$ CFU and 0 to $0.35 \log _{10}$ CFU reduction in final bacterial cell counts at concentrations between $7.5 \mathrm{mg} / \mathrm{g}$ to $20 \mathrm{mg} / \mathrm{g}$ at $4{ }^{\circ} \mathrm{C}$ and $10{ }^{\circ} \mathrm{C}$, respectively, in comparison to the cell counts from the positive control (Figure 4). On smoked salmon the pieces had lower cell counts than what they had been inoculated with, indicating that PEA in addition to inhibiting cell 
division, also impacted the survival of the bacteria (Figure 4; Supplementary Figure S4). This reduction trend increased with increasing PEA concentration but was only statistically significant at $20 \mathrm{mg} / \mathrm{g}$. At the lowest concentration $(7.5 \mathrm{mg} / \mathrm{g})$ tested, PEA had no longer an effect on bacterial cell count, in fact, it appeared the counts were higher than those of the positive control though the difference was not statistically significant (Figures 3 and 4; Supplementary Figures S3 and S4). Overall there were no observable differences in bacterial chaining observed among the strains for all the different meat and salmon experimental setups, ruling out the possibility that differences observed in CFU counts could have been distorted due to differences in bacterial chaining under the different PEA treatment conditions.

A

PEA treated Lyoner at $4^{\circ} \mathrm{C}$

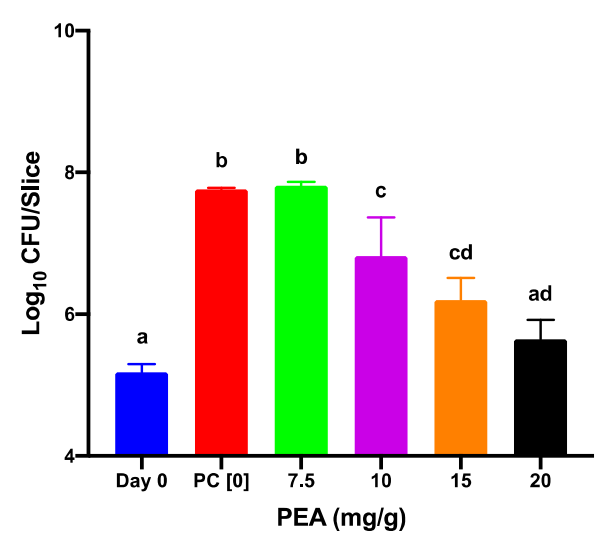

C PEA treated Lyoner at $10^{\circ} \mathrm{C}$

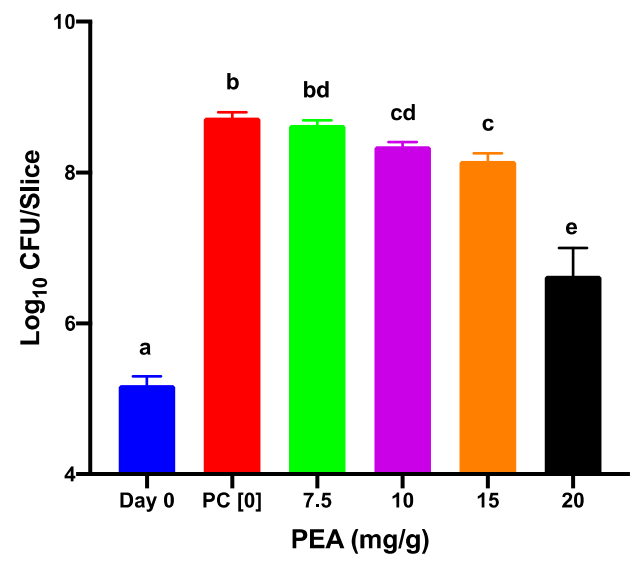

B

PEA treated Lyoner at $4^{\circ} \mathrm{C}$

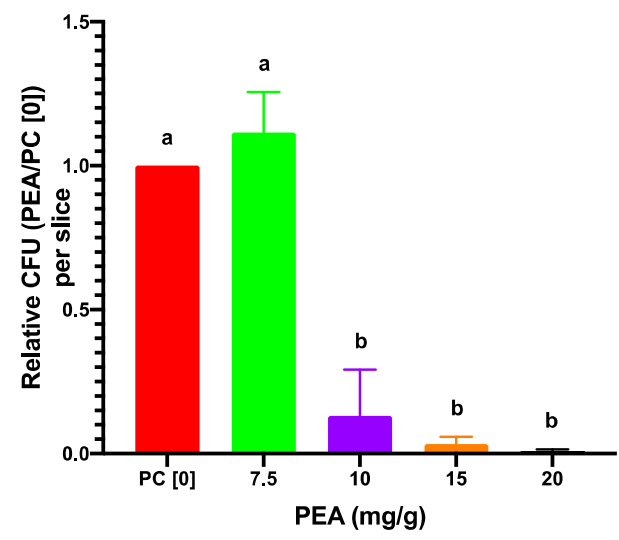

D

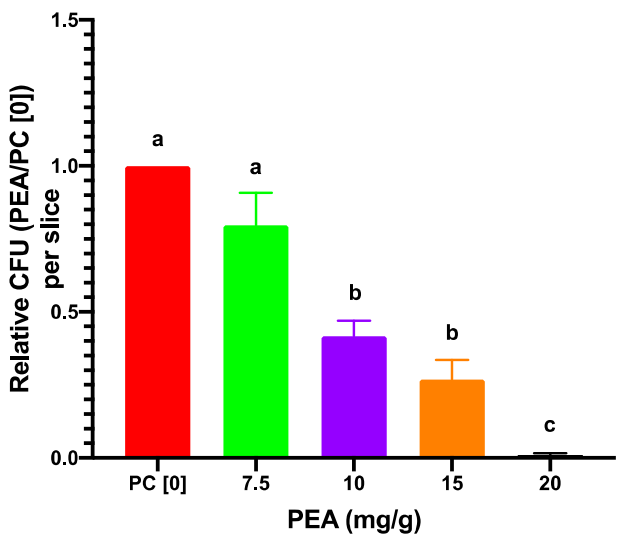

Figure 3. Effect of PEA on bacterial counts on lyoner sausage treated with different PEA concentrations and contaminated with a cocktail of four L. monocytogenes strains and stored for 11 and 7 days at $4{ }^{\circ} \mathrm{C}$ $(\mathbf{A}, \mathbf{B})$ or $10^{\circ} \mathrm{C}(\mathbf{C}, \mathbf{D})$, respectively. (A,C): Viable bacterial counts were determined and expressed in Log CFU per slice. (B,D): CFU levels determined per PEA lyoner slice expressed relative to those of the positive control with no PEA added (PC [0]) slices. PC [0] denotes the positive control sample (PEA untreated, L. monocytogenes inoculated slices). Data shown are the mean (bars) and standard deviation of three biological replicates. Different letters indicate significant differences between treatments that were identified through one-way ANOVA and Tukey post-hoc test pairwise comparison of all the treatment conditions $(p<0.05)$. 
A

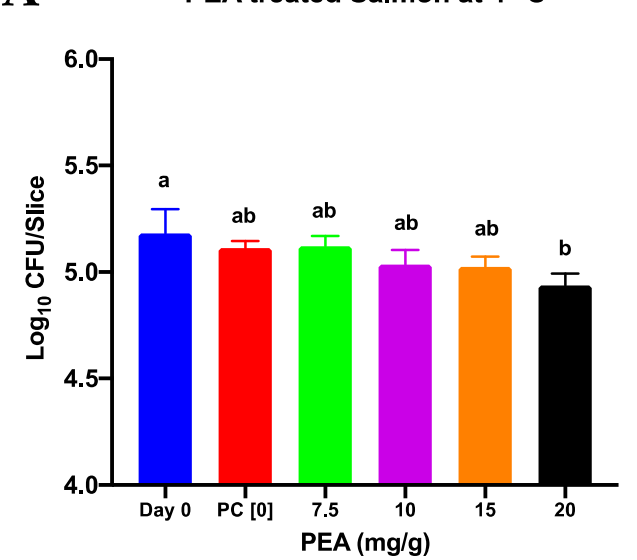

C

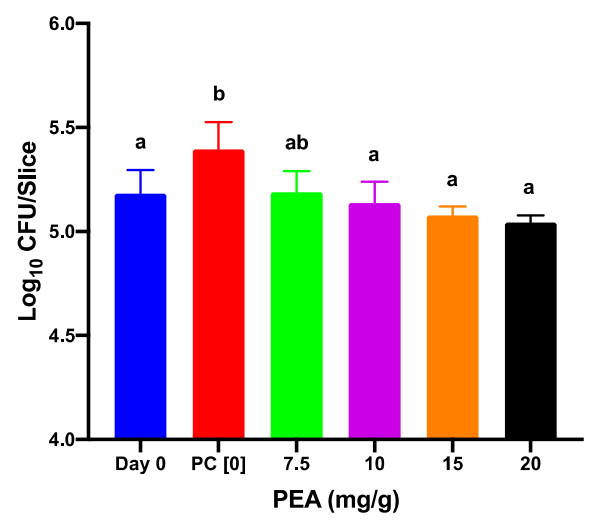

B

PEA treated Salmon at $4^{\circ} \mathrm{C}$

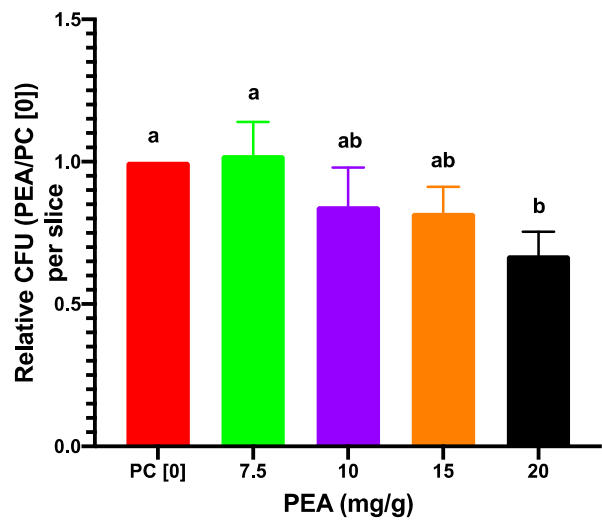

D

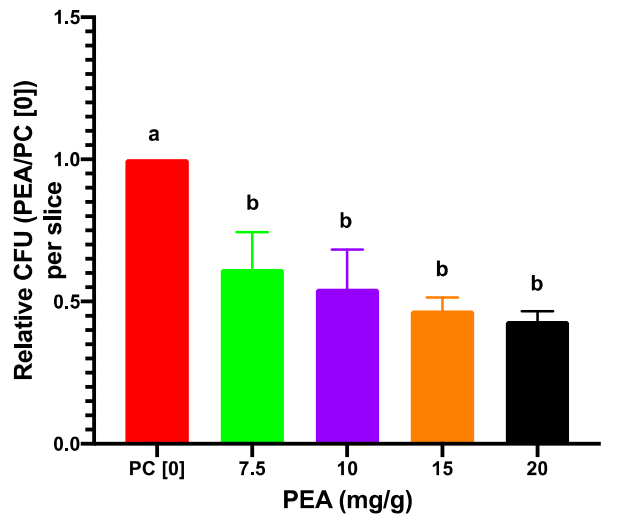

Figure 4. Effect of PEA on bacterial counts on smoked salmon slices treated with varying PEA concentrations and contaminated with a cocktail of four L. monocytogenes strains and stored for 11 days at $4{ }^{\circ} \mathrm{C}(\mathbf{A}, \mathbf{B})$ or 7 days at $10{ }^{\circ} \mathrm{C}(\mathbf{C}, \mathbf{D})$. (A,C): Viable bacterial counts were determined and expressed in Log CFU per slice. (B,D): CFU levels determined per PEA smoked salmon slice expressed relative to those of the PC [0] slices. PC [0] denotes the positive control sample (PEA untreated, L. monocytogenes inoculated slices). Data shown are the mean (bars) and standard deviation of three biological replicates. Different letters indicate significant differences $(p<0.05)$ that were identified through one-way ANOVA and Tukey post-hoc pairwise comparison test of all the treatment conditions.

\subsection{PEA Reduces L. monocytogenes Biofilm Production}

Since biofilm production can facilitate the long-term persistence and survival of isolates in the food processing plants the effect of PEA on biofilm production was assessed. PEA applied at 3.13 and $6.25 \mathrm{mg} / \mathrm{mL}$ caused a significant reduction of biofilm production in a strain dependent manner (Figure 5; Supplementary Figure S5). Notably, the greatest PEA inhibitory effect on biofilm production was observed on the high biofilm producing strains (N11-1850, N12-1772 and N13-0119 (Figure 5). Biofilm forming ability was variable amongst the tested strains and inhibition thereof by PEA did not follow any particular genetic background associated trend. 


\section{Biofilm Production}

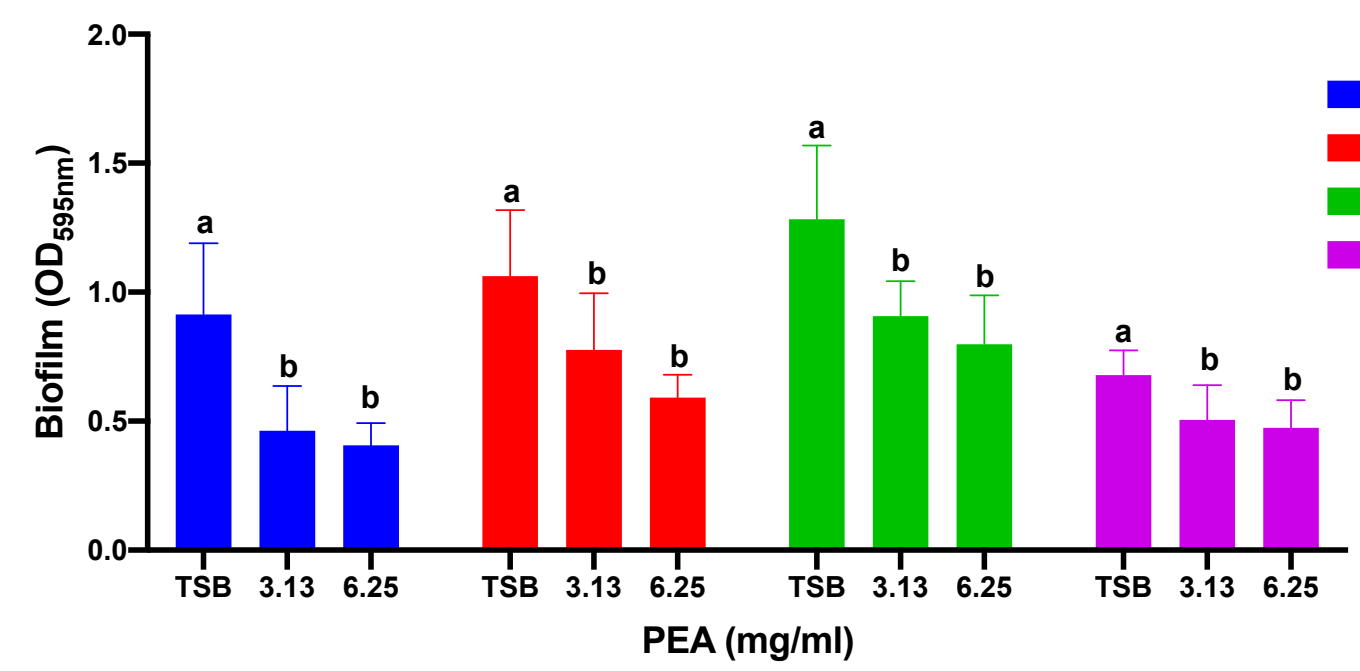

Figure 5. PEA reduces biofilm production. Presented data show the mean (bars) and standard deviation (error bars) of three independent biological experiments for selected strains representing lineage I, II and III. Data for biofilm formation were normalized relative to growth (OD $600 \mathrm{~nm}$ reading at $96 \mathrm{~h}$ ). For each strain different letters indicate significant difference between biofilm produced when grown in TSB compared to when grown in TSB supplemented with PEA at sub-MIC concentrations. $p<0.05$ based on one-way ANOVA and Tukey post-hoc test pairwise comparison of all the strains.

\section{Discussion}

In this study, we determined that PEA was effective at inhibiting growth and reducing viable cell counts of L. monocytogenes on BHI agar and in BHI broth as well as in MSM broth. The anti-listeria activity of PEA was not affected by pasteurization conditions, which is key to its potential application in the recipe for heat treated products. PEA also decreased the capacity of L. monocytogenes to produce biofilms. The results, moreover, highlight the need to incorporate a good selection of strain diversity for the development and validation of interventions for L. monocytogenes control on foods. As shown here the widely used L. monocytogenes EGDe reference strain had the highest PEA sensitivity amongst the tested strains. In comparison to commonly used food additives with antimicrobial activity such as nisin and sodium chloride which mainly have bacteriostatic activity, PEA has both bacteriostatic and bactericidal activity though significantly higher concentrations are required for similar bacteriostatic activity in comparison to nisin [47,48].

Results from in vitro studies are, however, limited to mimic the situation in different food products. Therefore, we performed an additional study trial using selected foods. These experiments on a bologna type sausage (lyoner) and cold smoked salmon pieces showed that PEA had inhibitory and bactericidal activity against $L$. monocytogenes on these products. The effect was more pronounced in the liquid media than on the food products signifying the importance of confirming in vitro findings on the end products intended for the intervention. However, the trends demonstrated both, in liquid media and the food products, indicated increased inhibition with increasing PEA concentration. As previously described for other antimicrobials, the reduced activity on food products vs. liquid media or agar might be influenced by factors such as uneven distribution or low solubility in the food matrix, adsorption of the antimicrobial to food constituents, and inactivation or degradation by enzymes or commensal microbiota $[38,89]$.

L. monocytogenes seems to be more sensitive to PEA stress on food matrices in comparison to some microorganisms as significant PEA bacteriostatic or bactericidal activity was observed at lower concentrations (10 to $20 \mathrm{mg} / \mathrm{g}$ PEA) whilst for E. coli it was observed at higher levels ( $\geq 70 \mathrm{mg} / \mathrm{mL})[65,69]$.

The lack of a stronger inhibitory effect of PEA on L. monocytogenes on salmon than on lyoner could be linked to uneven distribution of PEA on the food matrix. Future analysis might need to test 
different PEA application methods such as injection during processing or fine mist spray to improve the distribution of PEA. Furthermore, as alluded to above some cold smoked salmon matrix intrinsic factors including commensal microbiota could have contributed to the decreased PEA antimicrobial activity observed on salmon. More work needs to be done to determine how further efficiency can be achieved by using higher concentrations of PEA or when combining this intervention with other hurdle techniques such as salt, nisin, high-pressure treatment, and vacuum packaging.

The contamination levels of $L$. monocytogenes used in our study are significantly higher than usual since initial natural contamination levels when present are usually below $10 \mathrm{CFU} / \mathrm{g}$ [23]. The higher contamination levels applied in this study were chosen to enable the detection and quantification of the effects of the interventions on the bacteria. Furthermore, we wanted to limit the "Jameson effect" due to the competitive microbiota of the foods as microbial growth might be greatly inhibited once the predominant bacteria species has reached its maximum population density [90].

The formation of nonculturable but viable L. monocytogenes cells during the PEA application could be an explanation for what appears as a bactericidal effect observed on salmon stored at $4{ }^{\circ} \mathrm{C}$. However, in the BHI growth assays, we observed an absence of respiration or metabolic activity using TTC dye, hence it can be assumed that the bacteria had died. Moreover, stressors such as low temperature, $\mathrm{pH}$ and osmotic stress can induce chaining or filamentation in L. monocytogenes due to incomplete cell separation post cell division [91,92]. This would lead to an underestimation of the actual bacteria numbers in direct plate counts because several cells in a chain will produce a single colony. Hence, the probability of chaining must be taken into account when drawing conclusions from reduced cell counts of L. monocytogenes on foods after adding a stressor. In our study, however, the analysis for chaining revealed that PEA exposure did not result in any observable increase in chaining as determined by analysis of Gram stained slides.

The effects of most salts such as sodium lactate have been ascribed to $\mathrm{pH}$ and water activity reduction [93]. In our study, no significant changes in $\mathrm{pH}$ or water activity in the PEA treated samples were observed. The values where at a level at which no impact on L. monocytogenes growth would be expected. It seems PEA exerts an antimicrobial effect on the growth of L. monocytogenes that is independent of changes in $\mathrm{pH}$ and water activity.

Attempts to influence bacterial signal transduction pathways with substances such as PEA have been investigated in a selection of pathogens. For example, some infections by E. coli can be treated through quorum sensing and two-component signaling systems targeting antimicrobials such as LED209 and ZFH-02056 [94-97]. It has also been suggested by others that a similar system could be responsible for E. coli response to PEA stress $[65,68]$. This two-component system might transmit signals to multiplication and cell division probably mimicking the signals of a culture in stationary phase thereby inhibiting multiplication and possibly inducing autolysis. Going forward our research will focus on detailing the mechanism of PEA action.

High biofilm production ability and resistance to disinfectants are key for L. monocytogenes persistence in food processing environment $[3,54,59,63,64]$. Biofilms offer protection from the harsh environment that exists in the food processing environment. The presence of high biofilm producing $L$. monocytogenes strains, coupled with unhygienic substandard processing practices and poor maintenance and sanitation of processing plants, are major contributors to contamination of foods with $L$. monocytogenes $[3,15,37]$. From our data, L. monocytogenes biofilm production can be reduced by PEA, hence integrating PEA into cleaning routines especially on food contact surfaces where some disinfectants might not be suitable could contribute to reduction of contamination levels and persistence of L. monocytogenes in food processing plants. Although not all strains biofilm ability was reduced, the concentrations used were below the MIC and some of these strains might have required a higher concentration for biofilm production to be inhibited, future studies need to clarify this. However, a positive aspect is that the high biofilm formers were significantly inhibited in their biofilm forming ability at low concentrations. The biofilm experiments were done in vitro using attachment surfaces 
that might be different from those existing within some parts of the processing plant environment, hence any conclusions must be made with this limitation in mind.

The potential application of PEA might be exploited as a safe food bio preservative for use with substances such as nisin to which resistance is rising thereby minimizing the L. monocytogenes nisin-resistance problem $[43-45,47]$. As previously suggested by others, one possible way to use PEA is to add it during product formulation or injecting or spraying the food product as a decontamination treatment [65]. Another attractive application of PEA would be to put high concentrations of PEA in packaging films and protective coatings as was shown with sodium lactate $(\mathrm{NaL})$ plus nisin, NaL plus sodium diacetate, and mustard extract or sinigrin impregnated films that prevented L. monocytogenes growth on cold smoked salmon and bologna sausages, respectively [98-100]. This technique becomes more relevant were antimicrobial ingredient addition to the food product during formulation is not desirable. Another alternative could be to use it to treat food contact surfaces to avoid cross-contamination of products. Since food contact surfaces provide an ideal environment for pathogenic bacteria such as L. monocytogenes to form biofilm on [101-103], PEA can also be used to treat these as we could show that it reduces L. monocytogenes biofilm production. Future studies must tackle the practical nature of specific applications, treatments, and combinations which would be synergistic or additive minimizing induction of cross protection such as is observed with $\mathrm{NaCl}$ and nisin at low temperatures $[43,45]$. Since the effects of PEA appear to be concentration dependent, maximum legally permissible concentrations that do not alter product quality must be established for each product. Likewise, the effectiveness against other food contaminating pathogens beyond L. monocytogenes in the context of RTE foods must be determined.

Potential drawbacks to application of amines such as PEA in foods include their potential negative health effects to segments of the population with limited amine degradation capacity due to factors that are hereditary or associated with alcoholism and use of monoamine oxidase inhibiting medications [104]. Future research must address these questions especially the determination of maximum allowable inclusion levels that avoid these negative biological effects. In food products that undergo high heat or smoke treatment and are exposed to acidic conditions the potential of carcinogenic nitrosamine formation in meat products containing nitrates or nitrites might be a limiting factor to PEA application in such products [105]. However, to circumvent this problem, PEA could potentially be applied post heat or smoke treatment or via other alternative application methods as described above in such products. It is important to note that the final concentration, if any, of nitrosamines that might be formed would be influenced by heating or cooking method, $\mathrm{pH}$, and duration of the process applied [105]. Limiting cooking time and addition of natural nitrosation inhibiting substances such as the vitamins, alpha-tocopherol, and ascorbic acid might, therefore, be applied to mitigate this risk [105]. It remains to be determined whether PEA increases or induces nitrosamine formation in those products where a risk of their formation could be introduced or increased by PEA addition.

In conclusion, our data suggest that PEA could be applied as an anti-listerial natural food additive. Based on good manufacturing practices as a prerequisite, the application of PEA to RTE products might be an additional hurdle to limit $L$. monocytogenes growth, thereby increasing food safety.

Supplementary Materials: The following are available online at http://www.mdpi.com/2304-8158/9/10/1363/s1, Figure S1: Distribution of isolates across MLST Clonal complexes, Figure S2: PEA has inhibitory and bactericidal activity against L. monocytogenes, Figure S3: Effect of PEA on L. monocytogenes growth on lyoner slices treated with different PEA concentrations and inoculated with a cocktail of four L. monocytogenes strains, Figure S4: Effect of PEA on L. monocytogenes growth on smoked salmon slices treated with different PEA concentrations and inoculated with a cocktail of four L. monocytogenes strains, Figure S5: Effect of $\beta$-phenylethylamine (PEA) on biofilm production, Table S1: L. monocytogenes EGDe growth kinetics at different PEA concentrations, Table S2: Study strains and their PEA MIC in different media, Table S3: Clonal Complex and PEA MICs, Table S4: Working solution $\mathrm{pH}$ and water activity.

Author Contributions: Conceptualization and methodology F.M., R.S. and T.T., F.M. investigation, validation, data curation, formal analysis, writing-original draft preparation, review and editing. R.S. and T.T. supervision, visualization, data analysis, review and editing. All authors have read and agreed to the published version of the manuscript. 
Funding: This work was funded by the University of Zürich and received no external funding.

Acknowledgments: The authors would like to thank Ueli von Ah and the Agroscope media preparation team (Agroscope, Bern, Switzerland) for providing the meat simulation media used in this study.

Conflicts of Interest: The authors declare that the research was conducted in the absence of any commercial or financial relationships that could be construed as a potential conflict of interest.

\section{References}

1. Centers for Disease Control (CDC). Centre for disease control and prevention. Preliminary incidence and trends of infections with pathogens transmitted commonly through food. Foodborne Diseases Active Surveillance Network, 10 U.S. Sites, 2006-2017. MMWR Morb. Mortal. Wkly. Rep. 2018, 67, 324-328. [CrossRef]

2. European Food Safety Authority (EFSA). The European Union summary report on trends and sources of zoonoses, zoonotic agents and food-borne outbreaks in 2017. EFSA J. 2018, 16, e05500. [CrossRef]

3. Buchanan, R.; Gorris, L.G.M.; Hayman, M.M.; Jackson, T.C.; Whiting, R.C. A review of Listeria monocytogenes: An update on outbreaks, virulence, dose-response, ecology, and risk assessments. Food Control 2017, 75, 1-13. [CrossRef]

4. Cartwright, E.J.; Jackson, K.A.; Johnson, S.D.; Graves, L.M.; Silk, B.J.; Mahon, B.E. Listeriosis Outbreaks and Associated Food Vehicles, United States, 1998-2008. Emerg. Infect. Dis. 2013, 19, 1-9. [CrossRef]

5. European Food Safety Authority (EFSA); European Centre for Disease Prevention and Control (ECDC). The European Union One Health 2018 Zoonoses Report. EFSA J. 2019, 17, 5926. Available online: https://efsa.onlinelibrary.wiley.com/doi/epdf/10.2903/j.efsa.2019.5926 (accessed on 6 August 2020).

6. FDA. Quantitative Assessment of Relative Risk to Public Health from Foodborne Listeria monocytogenes among Selected Categories of Ready-to-Eat Foods. In Appendix 12: Cluster Analysis for Grouping of Food Categories; 2003. Available online: https://www.fda.gov/media/124721/download (accessed on 18 August 2020).

7. Gombas, D.E.; Chen, Y.; Clavero, R.S.; Scott, V.N. Survey of Listeria monocytogenes in Ready-to-Eat Foods. J. Food Prot. 2003, 66, 559-569. [CrossRef]

8. Hächler, H.; Marti, G.; Giannini, P.; Lehner, A.; Jost, M.; Beck, J.; Weiss, F.; Bally, B.; Jermini, M.; Stephan, R.; et al. Outbreak of Listerosis due to Imported Cooked Ham, Switzerland 2011. Eurosurveillance 2013, 18. Available online: http://www.eurosurveillance.org/ViewArticle.aspx?ArticleId=20469 (accessed on 11 August 2020). [CrossRef]

9. Stephan, R.; Althaus, D.; Kiefer, S.; Lehner, A.; Hatz, C.; Schmutz, C.; Jost, M.; Gerber, N.; Baumgartner, A.; Hächler, H.; et al. Foodborne transmission of Listeria monocytogenes via ready-to-eat salad: A nationwide outbreak in Switzerland, 2013-2014. Food Control 2015, 57, 14-17. [CrossRef]

10. Tchatchouang, C.-D.K.; Fri, J.; De Santi, M.; Brandi, G.; Schiavano, G.F.; Amagliani, G.; Ateba, C.N. Listeriosis Outbreak in South Africa: A Comparative Analysis with Previously Reported Cases Worldwide. Microorganisms 2020, 8, 135. [CrossRef]

11. Althaus, D.; Jermini, M.; Giannini, P.; Martinetti, G.; Reinholz, D.; Nüesch-Inderbinen, M.; Lehner, A.; Stephan, R. Local Outbreak of Listeria monocytogenes Serotype $4 \mathrm{~b}$ Sequence Type 6 due to Contaminated Meat Pâté. Foodborne Pathog. Dis. 2017, 14, 219-222. [CrossRef]

12. Gallagher, D.L.; Ebel, E.D.; Kause, J.R. FSIS Risk Assessment for Listeria monocytogenes in Deli Meats. 2003. Available online: https://www.fsis.usda.gov/shared/PDF/Lm_Deli_Risk_Assess_Final_2003.pdf (accessed on 5 August 2020).

13. Jensen, A.K.; Nielsen, E.M.; Björkman, J.; Müller, L.; Persson, S.; Bjerager, G.; Perge, A.; Krause, T.G.; Kiil, K.; Sørensen, G.; et al. Whole-genome sequencing used to investigate a nationwide outbreak of listeriosis caused by ready-to-eat delicatessen meat, Denmark, 2014. Clin. Infect. Dis. 2016, 63, 64-70. [CrossRef]

14. Olsen, S.J.; Patrick, M.; Hunter, S.B.; Reddy, V.; Kornstein, L.; MacKenzie, W.R.; Lane, K.; Bidol, S.; Stoltman, G.A.; Frye, D.M.; et al. Multistate Outbreak of Listeria monocytogenes Infection Linked to Delicatessen Turkey Meat. Clin. Infect. Dis. 2005, 40, 962-967. [CrossRef]

15. EFSA Panel on Biological Hazards (BIOHAZ); Ricci, A.; Allende, A.; Bolton, D.; Chemaly, M.; Davies, R.; Escámez, P.S.F.; Gironés, R.; Herman, L.; Koutsoumanis, K.; et al. Listeria monocytogenes contamination of ready-to-eat foods and the risk for human health in the EU. EFSA J. 2018, 16, e05134. [CrossRef] 
16. Anderson, A.L.; Verrill, L.A.; Sahyoun, N. Food Safety Perceptions and Practices of Older Adults. Public Health Rep. 2011, 126, 220-227. [CrossRef]

17. Goulet, V.; Hedberg, C.; Le Monnier, A.; De Valk, H. Increasing Incidence of Listeriosis in France and Other European Countries. Emerg. Infect. Dis. 2008, 14, 734-740. [CrossRef]

18. Interagency Food Safety Analytics Collaboration (IFSAC). Foodborne Illness Source Attribution Estimates for 2017 for Salmonella, Escherichia Coli O157, Listeria Monocytogenes, and Campylobacter Using Multi-Year Outbreak Surveillance Data, United States; U.S. Department of Health and Human Services, CDC, FDA, USDA-FSIS: Atlanta, Georgia; Washington, DC, USA, 2019. Available online: https:/www.cdc.gov/foodsafety/ifsac/pdf/ P19-2017-report-TriAgency-508.pdf (accessed on 6 August 2020).

19. Wambogo, E.; Vaudin, A.M.; Moshfegh, A.J.; Spungen, J.H.; Van Doren, J.M.; Sahyoun, N.R. Toward a Better Understanding of Listeriosis Risk among Older Adults in the United States: Characterizing Dietary Patterns and the Sociodemographic and Economic Attributes of Consumers with These Patterns. J. Food Prot. 2020, 83, 1208-1217. [CrossRef]

20. FDA. Listeria monocytogenes Risk Assessment: I. Introduction. FDA/Center for Food Safety and Applied Nutrition, USDA/Food Safety and Inspection Service. 2003. Available online: http://www. centerforproducesafety.org/amass/documents/document/270/Risk\%20\&\%20Safety\%20Assessment\%20_ \%20_i_Listeria\%20monocytogenes_i_\%20Risk\%20Assessment.pdf (accessed on 10 August 2020).

21. Archer, D.L. The evolution of FDA's policy on Listeria monocytogenes in ready-to-eat foods in the United States. Curr. Opin. Food Sci. 2018, 20, 64-68. [CrossRef]

22. European Commission. Commission Regulation (EC) No. 2073/2005 of 15 November 2005 on microbiological criteria for foodstuffs. Off. J. Eur. Union L 2005, 338, 1-26.

23. Aalto-Araneda, M.; Lundén, J.; Markkula, A.; Hakola, S.; Korkeala, H. Processing plant and machinery sanitation and hygiene practices associate with Listeria monocytogenes occurrence in ready-to-eat fish products. Food Microbiol. 2019, 82, 455-464. [CrossRef]

24. Bredholt, S.; Nesbakken, T.; Holck, A. Protective cultures inhibit growth of Listeria monocytogenes and Escherichia coli O157:H7 in cooked, sliced, vacuum- and gas-packaged meat. Int. J. Food Microbiol. 1999, 53, 43-52. [CrossRef]

25. Bredholt, S.; Nesbakken, T.; Holck, A. Industrial application of an antilisterial strain of Lactobacillus sakei as a protective culture and its effect on the sensory acceptability of cooked, sliced, vacuum-packaged meats. Int. J. Food Microbiol. 2001, 66, 191-196. [CrossRef]

26. Buncic, S.; Nychas, G.-J.; Lee, M.R.F.; Koutsoumanis, K.; Hébraud, M.; Desvaux, M.; Chorianopoulos, N.; Bolton, D.; Blagojevic, B.; Antic, D. Microbial pathogen control in the beef chain: Recent research advances. Meat Sci. 2014, 97, 288-297. [CrossRef]

27. Levine, P.; Rose, B.; Green, S.; Ransom, G.; Hill, W. Pathogen Testing of Ready-to-Eat Meat and Poultry Products Collected at Federally Inspected Establishments in the United States, 1990 to 1999. J. Food Prot. 2001, 64, 1188-1193. [CrossRef]

28. Mellefont, L.; Ross, T. Effect of Potassium Lactate and a Potassium Lactate-Sodium Diacetate Blend on Listeria monocytogenes Growth in Modified Atmosphere Packaged Sliced Ham. J. Food Prot. 2007, 70, 2297-2305. [CrossRef]

29. Moye, Z.D.; Woolston, J.; Sulakvelidze, A. Bacteriophage Applications for Food Production and Processing. Viruses 2018, 10, 205. [CrossRef]

30. Porto, A.C.S.; Franco, B.D.G.M.; Sant'Anna, E.S.; Call, J.E.; Piva, A.; Luchansky, J.B. Viability of a Five-Strain Mixture of Listeria monocytogenes in Vacuum-Sealed Packages of Frankfurters, Commercially Prepared with and without 2.0 or $3.0 \%$ Added Potassium Lactate, during Extended Storage at 4 and $10{ }^{\circ} \mathrm{C}$. J. Food Prot. 2002, 65, 308-315. [CrossRef]

31. Porto-Fett, A.; Campano, S.; Smith, J.; Oser, A.; Shoyer, B.; Call, J.; Luchansky, J.B. Control of Listeria monocytogenes on commercially-produced frankfurters prepared with and without potassium lactate and sodium diacetate and surface treated with lauric arginate using the Sprayed Lethality in Container (SLIC ${ }^{\circledR}$ ) delivery method. Meat Sci. 2010, 85, 312-318. [CrossRef]

32. Kaban, G.; Kaya, M.; Lücke, F.-K. The effect of Lactobacillus sakei on the behavior of listeria monocytogenes on sliced bologna-type sausages. J. Food Saf. 2010, 30, 889-901. [CrossRef]

33. Mei, J.; Ma, X.; Xie, J. Review on Natural Preservatives for Extending Fish Shelf Life. Foods 2019, 8, 490. [CrossRef] 
34. Ross, T.; Rasmussen, S.; Sumner, J.; Paoli, G.; Fazil, A. Listeria monocytogenes in Australian processed meat products: Risks and their management. Rep. Meat Livest. Aust. Syd. 2004, 2059, 2004.

35. Tompkin, R.B. Control of Listeria monocytogenes in the Food-Processing Environment. J. Food Prot. 2002, 65, 709-725. [CrossRef]

36. Vijayakumar, P.P.; Muriana, P.M. Inhibition of Listeria monocytogenes on Ready-to-Eat Meats Using Bacteriocin Mixtures Based on Mode-of-Action. Foods 2017, 6, 22. [CrossRef]

37. Bucur, F.I.; Grigore-Gurgu, L.; Crauwels, P.; Riedel, C.U.; Nicolau, A.I. Resistance of Listeria monocytogenes to Stress Conditions Encountered in Food and Food Processing Environments. Front. Microbiol. 2018, 9, 2700. [CrossRef]

38. Cleveland, J.; Montville, T.J.; Nes, I.F.; Chikindas, M.L. Bacteriocins: Safe, natural antimicrobials for food preservation. Int. J. Food Microbiol. 2001, 71, 1-20. [CrossRef]

39. Eicher, C.; Subira, A.R.; Corti, S.; Meusburger, A.; Stephan, R.; Guldimann, C. Growth Potential of Listeria monocytogenes in Three Different Salmon Products. Foods 2020, 9, 1048. [CrossRef]

40. Samelis, J.; Sofos, J.N.; Kain, M.L.; Scanga, J.A.; Belk, K.E.; Smith, G.C. Organic Acids and Their Salts as Dipping Solutions To Control Listeria monocytogenes Inoculated following Processing of Sliced Pork Bologna Stored at $4{ }^{\circ} \mathrm{C}$ in Vacuum Packages. J. Food Prot. 2001, 64, 1722-1729. [CrossRef]

41. Ouattara, B.; Simard, R.E.; Holley, R.A.; Piette, G.J.-P.; Bégin, A. Antibacterial activity of selected fatty acids and essential oils against six meat spoilage organisms. Int. J. Food Microbiol. 1997, 37, 155-162. [CrossRef]

42. Bergholz, T.M.; Bowen, B.; Wiedmann, M.; Boor, K.J. Listeria monocytogenes Shows Temperature-Dependent and -Independent Responses to Salt Stress, Including Responses That Induce Cross-Protection against Other Stresses. Appl. Environ. Microbiol. 2012, 78, 2602-2612. [CrossRef]

43. Bergholz, T.M.; Tang, S.; Wiedmann, M.; Boor, K.J. Nisin Resistance of Listeria monocytogenes Is Increased by Exposure to Salt Stress and Is Mediated via LiaR. Appl. Environ. Microbiol. 2013, 79, 5682-5688. [CrossRef]

44. Davies, E.; Adams, M. Resistance of Listeria monocytogenes to the bacteriocin nisin. Int. J. Food Microbiol. 1994, 21, 341-347. [CrossRef]

45. De Martinis, E.C.P.; Crandall, A.D.; Mazzotta, A.S.; Montville, T.J. Influence of pH, Salt, and Temperature on Nisin Resistance in Listeria monocytogenes. J. Food Prot. 1997, 60, 420-423. [CrossRef]

46. Gandhi, M.; Chikindas, M.L. Listeria: A foodborne pathogen that knows how to survive. Int. J. Food Microbiol. 2007, 113, 1-15. [CrossRef]

47. Henderson, L.O.; Flores, B.J.E.; Skeens, J.; Kent, D.; Murphy, S.I.; Wiedmann, M.; Guariglia-Oropeza, V. Nevertheless, She Resisted-Role of the Environment on Listeria monocytogenes Sensitivity to Nisin Treatment in a Laboratory Cheese Model. Front. Microbiol. 2020, 11, 635. [CrossRef]

48. Schmid, B.; Klumpp, J.; Raimann, E.; Loessner, M.J.; Stephan, R.; Tasara, T. Role of Cold Shock Proteins in Growth of Listeria monocytogenes under Cold and Osmotic Stress Conditions. Appl. Environ. Microbiol. 2009, 75, 1621-1627. [CrossRef]

49. Alves, Â.; Magalhães, R.; Brandão, T.R.; Pimentel, L.; Rodríguez-Alcalá, L.M.; Teixeira, P.; Ferreira, V. Impact of exposure to cold and cold-osmotic stresses on virulence-associated characteristics of Listeria monocytogenes strains. Food Microbiol. 2020, 87, 103351. [CrossRef]

50. Garner, M.R.; James, K.E.; Callahan, M.C.; Wiedmann, M.; Boor, K.J. Exposure to Salt and Organic Acids Increases the Ability of Listeria monocytogenes To Invade Caco-2 Cells but Decreases Its Ability to Survive Gastric Stress. Appl. Environ. Microbiol. 2006, 72, 5384-5395. [CrossRef]

51. Barbosa, J.; Borges, S.; Magalhães, R.; Ferreira, V.B.; Santos, I.; Silva, J.; Almeida, G.; Gibbs, P.; Teixeira, P. Behaviour of Listeria monocytogenes isolates through gastro-intestinal tract passage simulation, before and after two sub-lethal stresses. Food Microbiol. 2012, 30, 24-28. [CrossRef]

52. Pettersen, K.S.; Skjerdal, T.; Wasteson, Y.; Lindbäck, T.; Vegarud, G.; Comi, I.; Aspholm, M. Survival of Listeria monocytogenes during in vitro gastrointestinal digestion after exposure to 5 and $0.5 \%$ sodium chloride. Food Microbiol. 2019, 77, 78-84. [CrossRef]

53. Doyle, M.P.; Diez-Gonzalez, F.; Hill, C. Food Microbiology: Fundamentals and Frontiers; John Wiley and Sons: Hoboken, NJ, USA, 2019.

54. Kragh, M.L.; Muchaamba, F.; Tasara, T.; Hansen, L.T. Cold-shock proteins affect desiccation tolerance, biofilm formation and motility in Listeria monocytogenes. Int. J. Food Microbiol. 2020, 329, 108662. [CrossRef]

55. Warriner, K.; Namvar, A. Why is the hysteria with Listeria? Trends in Food? Sci. Technol. 2009, 20, $245-254$. 
56. Tasara, T.; Stephan, R. Cold Stress Tolerance of Listeria monocytogenes: A Review of Molecular Adaptive Mechanisms and Food Safety Implications. J. Food Prot. 2006, 69, 1473-1484. [CrossRef] [PubMed]

57. Chan, Y.C.; Wiedmann, M. Physiology and Genetics of Listeria monocytogenes Survival and Growth at Cold Temperatures. Crit. Rev. Food Sci. Nutr. 2008, 49, 237-253. [CrossRef] [PubMed]

58. Glass, K.A.; Doyle, M.P. Fate of Listeria monocytogenes in processed meat products during refrigerated storage. Appl. Environ. Microbiol. 1989, 55, 1565-1569. [CrossRef] [PubMed]

59. Borucki, M.K.; Peppin, J.D.; White, D.; Loge, F.; Call, D.R. Variation in Biofilm Formation among Strains of Listeria monocytogenes. Appl. Environ. Microbiol. 2003, 69, 7336-7342. [CrossRef] [PubMed]

60. Leong, D.; Alvarez-Ordóñez, A.; Jordan, K. Monitoring occurrence and persistence of Listeria monocytogenes in foods and food processing environments in the Republic of Ireland. Front. Microbiol. 2014, 5, 436. [CrossRef]

61. Orsi, R.H.; Borowsky, M.L.; Lauer, P.; Young, S.K.; Nusbaum, C.; Galagan, J.E.; Birren, B.; Ivy, R.A.; Sun, Q.; Graves, L.M.; et al. Short-term genome evolution of Listeria monocytogenes in a non-controlled environment. BMC Genom. 2008, 9, 539. [CrossRef]

62. Vongkamjan, K.; Roof, S.; Stasiewicz, M.J.; Wiedmann, M. Persistent Listeria monocytogenes subtypes isolated from a smoked fish processing facility included both phage susceptible and resistant isolates. Food Microbiol. 2013, 35, 38-48. [CrossRef]

63. Ferreira, V.B.; Wiedmann, M.; Teixeira, P.; Stasiewicz, M.J. Listeria monocytogenes Persistence in Food-Associated Environments: Epidemiology, Strain Characteristics, and Implications for Public Health. J. Food Prot. 2014, 77, 150-170. [CrossRef]

64. Stoller, A.; Stevens, M.J.A.; Stephan, R.; Guldimann, C. Characteristics of Listeria monocytogenes Strains Persisting in a Meat Processing Facility over a 4-Year Period. Pathogens 2019, 8, 32. [CrossRef]

65. Lynnes, T.; Horne, S.; Prüß, B. ß-phenylethylamine as a novel nutrient treatment to reduce bacterial contamination due to Escherichia coli O157:H7 on beef meat. Meat Sci. 2014, 96, 165-171. [CrossRef]

66. Kaewklom, S.; Lumlert, S.; Kraikul, W.; Aunpad, R. Control of Listeria monocytogenes on sliced bologna sausage using a novel bacteriocin, amysin, produced by Bacillus amyloliquefaciens isolated from Thai shrimp paste (Kapi). Food Control. 2013, 32, 552-557. [CrossRef]

67. Zhong, Y.; Wu, L.; Chen, X.; Huang, Z.-H.; Hu, W. Effects of Food-Additive-Information on Consumers' Willingness to Accept Food with Additives. Int. J. Environ. Res. Public Health 2018, 15, 2394. [CrossRef] [PubMed]

68. Irsfeld, M.; Spadafore, M.; Prüß, B.M. $\beta$-phenylethylamine, a small molecule with a large impact. Webmedcentral 2013, 4, 1-15.

69. Schroeder, M.; Horne, S.M.; Pruess, B. Efficacy of $\beta$-phenylethylamine as a novel anti-microbial and application as a liquid catheter flush. J. Med. Microbiol. 2018, 67, 1778-1788. [CrossRef]

70. European Commission. Commission Implementing Regulation (EU) No 872/2012 of 1 October 2012 adopting the list of flavouring substances provided for by Regulation (EC) No 2232/96 of the European Parliament and of the Council, introducing it in Annex I to Regulation (EC) No 1334/2008 of the European Parliament and of the Council and repealing Commission Regulation (EC) No 1565/2000 and Commission Decision 1999/217/EC (1). Off. J. Eur. Union L 2012, 267, 1-161. [CrossRef]

71. Joint FAO/WHO Expert Committee on Food Additives (JECFA). Evaluation of certain food additives. Sixty-fifth report of the joint FAO/WHO Expert Committee on food additives. WHO Tech. Rep. Ser. 2006, 934, 145.

72. Granvogl, M.; Bugan, S.; Schieberle, P. Formation of Amines and Aldehydes from Parent Amino Acids during Thermal Processing of Cocoa and Model Systems: New Insights into Pathways of the Strecker Reaction. J. Agric. Food Chem. 2006, 54, 1730-1739. [CrossRef]

73. Muchaamba, F.; Eshwar, A.K.; Stevens, M.J.A.; Von Ah, U.; Tasara, T. Variable Carbon Source Utilization, Stress Resistance, and Virulence Profiles Among Listeria monocytogenes Strains Responsible for Listeriosis Outbreaks in Switzerland. Front. Microbiol. 2019, 10, 957. [CrossRef]

74. Muchaamba, F.; Eshwar, A.K.; Von Ah, U.; Stevens, M.J.A.; Tasara, T. Evolution of Listeria monocytogenes During a Persistent Human Prosthetic Hip Joint Infection. Front. Microbiol. 2020, 11, 1726. [CrossRef]

75. Chen, R.; Skeens, J.; Orsi, R.H.; Wiedmann, M.; Guariglia-Oropeza, V. Pre-growth conditions and strain diversity affect nisin treatment efficacy against Listeria monocytogenes on cold-smoked salmon. Int. J. Food Microbiol. 2020, 333, 108793. [CrossRef]

76. Guyer, S.; Jemmi, T. Behavior of Listeria monocytogenes during fabrication and storage of experimentally contaminated smoked salmon. Appl. Environ. Microbiol. 1991, 57, 1523-1527. [CrossRef] [PubMed] 
77. Norton, D.M.; McCamey, M.A.; Gall, K.L.; Scarlett, J.M.; Boor, K.J.; Wiedmann, M. Molecular studies on the ecology of Listeria monocytogenes in the smoked fish processing industry. Appl. Environ. Microbiol. 2001, 67, 198-205. [CrossRef] [PubMed]

78. Sabanadesan, S.; Lammerding, A.M.; Griffiths, M.W. Survival of Listeria innocua in Salmon following Cold-Smoke Application. J. Food Prot. 2000, 63, 715-720. [CrossRef] [PubMed]

79. Bille, J. Epidemiology of Human Listeriosis in Europe with Special Reference to the Swiss Outbreak; Miller, A.J., Smith, J.L., Somkuti, G.A., Eds.; Foodborne listeriosis; Elsevier: New York, NY, USA, 1990; pp. 71-74.

80. Ebner, R.; Stephan, R.; Althaus, D.; Brisse, S.; Maury, M.; Tasara, T. Phenotypic and genotypic characteristics of Listeria monocytogenes strains isolated during 2011-2014 from different food matrices in Switzerland. Food Control 2015, 57, 321-326. [CrossRef]

81. Muchaamba, F.; Guldimann, C.; Tasara, T.; Mota, M.I.; Braga, V.; Varela, G.; Algorta, G.; Klumpp, J.; Jermini, M.; Stephan, R. Full-Genome Sequence of Listeria monocytogenes Strain H34, Isolated from a Newborn with Sepsis in Uruguay. Genome Announc. 2017, 5, e00544-17. [CrossRef]

82. Althaus, D.; Lehner, A.; Brisse, S.; Maury, M.; Tasara, T.; Stephan, R. Characterization of Listeria monocytogenes Strains Isolated During 2011-2013 from Human Infections in Switzerland. Foodborne Pathog. Dis. 2014, 11, 753-758. [CrossRef]

83. Fleming, D.W.; Holmes, M.B.; Audurier, A.; Cochi, S.L.; Macdonald, K.L.; Brondum, J.; Hayes, P.S.; Plikaytis, B.D.; Broome, C.V.; Reingold, A.L. Pasteurized Milk as a Vehicle of Infection in an Outbreak of Listeriosis. N. Engl. J. Med. 1985, 312, 404-407. [CrossRef]

84. Edman, D.C.; Pollock, M.B.; Hall, E.R. Listeria monocytogenes L Forms I. Induction, Maintenance, and Biological Characteristics1. J. Bacteriol. 1968, 96, 352-357. [CrossRef]

85. Bille, J.; Blanc, D.S.; Schmid, H.; Boubaker, K.; Baumgartner, A.; Siegrist, H.H.; Tritten, M.L.; Lienhard, R.; Berner, D.; Anderau, R.; et al. Outbreak of human listeriosis associated with tomme cheese in northwest Switzerland, 2005. Eurosurveillance 2006, 11, 11-12. [CrossRef]

86. Glaser, P.; Frangeul, L.; Buchrieser, C.; Rusniok, C.; Amend, A.; Baquero, F.; Berche, P.; Bloecker, H.; Brandt, P.; Chakraborty, T.; et al. Comparative genomics of Listeria species. Science 2001, 294, 849-852. [CrossRef]

87. Dreyer, M.; Aguilar-Bultet, L.; Rupp, S.; Guldimann, C.; Stephan, R.; Schock, A.; Otter, A.; Schüpbach, G.; Brisse, S.; Lecuit, M.; et al. Listeria monocytogenes sequence type 1 is predominant in ruminant rhombencephalitis. Sci. Rep. 2016, 6, 36419. [CrossRef] [PubMed]

88. Baranyi, J.; Roberts, T.A. A dynamic approach to predicting bacterial growth in food. Int. J. Food Microbiol. 1994, 23, 277-294. [CrossRef]

89. Lappi, V.R.; Ho, A.; Gall, K.; Wiedmann, M. Prevalence and Growth of Listeria on Naturally Contaminated Smoked Salmon over 28 Days of Storage at $4{ }^{\circ}$ C. J. Food Prot. 2004, 67, 1022-1026. [CrossRef] [PubMed]

90. Stephens, P.; Joynson, J.; Davies, K.; Holbrook, R.; Humphrey, T.; Lappin-Scott, H. The use of an automated growth analyser to measure recovery times of single heat-injured Salmonella cells. J. Appl. Microbiol. 1997, 83, 445-455. [CrossRef] [PubMed]

91. Liu, X.; Basu, U.; Miller, P.; McMullen, L.M. Differential gene expression and filamentation of Listeria monocytogenes 08-5923 exposed to sodium lactate and sodium diacetate. Food Microbiol. 2017, 63, 153-158. [CrossRef]

92. Vail, K.M.; McMullen, L.M.; Jones, T. Growth and Filamentation of Cold-Adapted, Log-Phase Listeria monocytogenes Exposed to Salt, Acid, or Alkali Stress at $3{ }^{\circ}$ C. J. Food Prot. 2012, 75, 2142-2150. [CrossRef]

93. De Wit, J.; Rombouts, F. Antimicrobial activity of sodium lactate. Food Microbiol. 1990, 7, 113-120. [CrossRef]

94. Rasko, D.A.; Moreira, C.G.; Li, D.R.; Reading, N.C.; Ritchie, J.M.; Waldor, M.K.; Williams, N.; Taussig, R.; Wei, S.; Roth, M.G.; et al. Targeting QseC Signaling and Virulence for Antibiotic Development. Science 2008, 321, 1078-1080. [CrossRef]

95. Kostakioti, M.; Hadjifrangiskou, M.; Pinkner, J.S.; Hultgren, S.J. QseC-mediated dephosphorylation of QseB is required for expression of genes associated with virulence in uropathogenic Escherichia coli. Mol. Microbiol. 2009, 73, 1020-1031. [CrossRef]

96. Hadjifrangiskou, M.; Kostakioti, M.; Chen, S.L.; Henderson, J.P.; Greene, S.E.; Hultgren, S.J. A central metabolic circuit controlled by QseC in pathogenic Escherichia coli. Mol. Microbiol. 2011, 80, 1516-1529. [CrossRef] 
97. Kostakioti, M.; Hadjifrangiskou, M.; Cusumano, C.K.; Hannan, T.J.; Janetka, J.W.; Hultgren, S.J. Distinguishing the contribution of type I pili from that of other QseB-misregulated factors when QseC is absent during urinary tract infections. Infect. Immun. 2012, 80, 2826-2834. [CrossRef] [PubMed]

98. Neetoo, H.; Ye, M.; Chen, H. Bioactive alginate coatings to control Listeria monocytogenes on cold-smoked salmon slices and fillets. Int. J. Food Microbiol. 2010, 136, 326-331. [CrossRef] [PubMed]

99. Neetoo, H.; Mahomoodally, M.F. Use of Antimicrobial Films and Edible Coatings Incorporating Chemical and Biological Preservatives to Control Growth of Listeria monocytogenes on Cold Smoked Salmon. BioMed Res. Int. 2014, 2014, 1-10. [CrossRef] [PubMed]

100. Lara-Lledó, M.; Olaimat, A.; Holley, R.A. Inhibition of Listeria monocytogenes on bologna sausages by an antimicrobial film containing mustard extract or sinigrin. Int. J. Food Microbiol. 2012, 156, 25-31. [CrossRef] [PubMed]

101. Renier, S.; Hébraud, M.; Desvaux, M. Molecular biology of surface colonization by Listeria monocytogenes: An additional facet of an opportunistic Gram-positive foodborne pathogen. Environ. Microbiol. 2010, 13, 835-850. [CrossRef] [PubMed]

102. Møretrø, T.; Langsrud, S. Listeria monocytogenes: Biofilm formation and persistence in food-processing environments. Biofilms 2004, 1, 107-121. [CrossRef]

103. Giaouris, E.; Heir, E.; Hébraud, M.; Chorianopoulos, N.; Langsrud, S.; Møretrø, T.; Habimana, O.; Desvaux, M.; Renier, S.; Nychas, G.-J. Attachment and biofilm formation by foodborne bacteria in meat processing environments: Causes, implications, role of bacterial interactions and control by alternative novel methods. Meat Sci. 2014, 97, 298-309. [CrossRef]

104. EFSA Panel on Biological Hazards (BIOHAZ). Scientific Opinion on Scientific Opinion on risk based control of biogenic amine formation in fermented foods. EFSA J. 2011, 9, 93. [CrossRef]

105. De Mey, E.; De Maere, H.; Paelinck, H.; Fraeye, I. VolatileN-nitrosamines in meat products: Potential precursors, influence of processing, and mitigation strategies. Crit. Rev. Food Sci. Nutr. 2015, 57, 2909-2923. [CrossRef]

(C) 2020 by the authors. Licensee MDPI, Basel, Switzerland. This article is an open access article distributed under the terms and conditions of the Creative Commons Attribution (CC BY) license (http://creativecommons.org/licenses/by/4.0/). 